\title{
Formation Stages Of Scientific And Technical Texts Translation
}

\author{
Nataliya Nikolayevna Gavrilenko \\ Peoples' Frienship University of Russia, \\ Mikluho-Maklaya str., 117198, Moscow, Russian Federation
}

\begin{abstract}
The main formation stages of scientific and technical texts translation in France and Russia have been considered in the article. Historiographers find the first references about a written translation of scientific texts in Ancient Greece and Rome. A new cycle of European translation tradition acting in two directions - South-Eastern Europe and Central Europe starts with disintegration of the Roman Empire into Eastern (Byzantine) and Western (Rome). The Arab School of Wisdom in Baghdad and the School of Translators in Toledo greatly influenced the development of those traditions.
\end{abstract}

Key words: special translation in Ancient Greece and Rome, Arab school of Wisdom, the school of translators in Toledo, special translation in Middle Ages in France and in Russia.

\section{INTRODUCTION}

A long way of historical development closely connected with the development of language, culture and science preceded the modern state of professionally-oriented translation. Each historical stage had different requirements to translation. V.N. Komissarov notes that "different forms of cultural determinancy for translation activity make up a specific conventional norm of translation - a body of requirements made by the society for translations at a certain stage of history" [8: 69]. A lot of researchers both in Russia and abroad have referred to the history of translation activity development for the whole century. However, all these researches have mainly been related to the history of the Bible translation development, literary translation while the history of professionally-oriented translation remains an underexamined object. The intention to broader define the concept of professionally-oriented translation made necessary to analyze Russian and foreign researches in the field of language, science and technology, cultural and translation science historical development. The conducted analysis permitted to highlight and describe the main, determining formation stages of the translation type being considered. The formation stages of professionally-oriented translation in the Ancient Greece, Roman Empire, Arab School of Wisdom, School in Toledo and in XV-XVII centuries in Russia and France will be presented.

\section{SCIENTIFIC AND TECHNICAL TEXTS TRANSLATION IN ANCIENT WORLD}

The development of the given type of translation was closely connected with the development of science and engineering. However, there is little data on the first principles of science and technology in ancient civilizations and the information is incomplete. There is considerably more data on development of science and engineering in Ancient Greece and Ancient Rome. "Greek civilization that succeeded Egypt and Babylon on the historical stage is a bright and amazing page in the history of mankind.

Greeks acquired the knowledge accumulated before and ever since the chronicle of science formation and development has not been interrupted." [7: 14]. These words written about science and engineering development can be also rightly referred to the history of professionally-oriented translation development. 


\section{Translation of scientific and technical texts in Ancient Greece.}

The translation of literary and administrative texts were the first to be mentioned in history. It is also noted that oral translation preceded the one in writing. The most ancient evidence of oral translation was found in Aswan, the decyphered inscriptions say that since 3000 B.C. rich Egyptians had private translators. Bilingualism of this border area next to Nubians and Greeks assisted to the appearance of first translators who left their traces in history. Herodotus, the Greek historian (about 484-425 B.C.) more than once mentioned about it underling that translators formed an independent caste. Since IX century B.C. there was a translation caste in ancient Carthage where representatives of almost 60 nationalities lived next to each other. The specific features of this caste members were shaved heads, tattoos with the pictures of parrots. If the parrot was with the lowered wings it meant that the translator knew only one language and if it had spread wings - the translator knew several languages. The proofs on availability of dictionaries both defining dictionaries with definitions, synonyms and multi-lingual ones have been preserved. The history written on a found papyrus (26402040 B.C.) testifies the existence of a written translation. It tells about a young scriber (a penman) who was instructed to translate an Egyptian book into the Greek language which told about Imhotep's mighty works and who was compared with the God of medicine. But the scriber was lazy and very slow with translation. Then a displeased Imhotep sent a disease on the translator and appeared in his dreams with a book in hands. Having correctly understood that message the scriber quickly finished the translation and recovered [5]. Nevertheless, the translation activity in the field of science and engineering in Ancient Greece was weakly developed as Greeks being assured in their superiority thought that foreigners had to study the Greek language.

\section{Translation of scientific and technical texts in Ancient Rome.}

The data on scientific and technical texts translation centers that we have are mainly related to the Roman Empire. The Romans as well as Greeks, did not feel a big demand in studying foreign languages. However, the Roman Empire was practically a bilingual state and the Greek language knowledge was an integral part of an educated Roman's intellectual baggage.

The inhabitants of Rome easily understood the Greek language, but sometimes the proper pride did not allow them to speak that language. That's why the Greek ambassadors' audiences in the Roman Senate required a compulsory presence of an interpreter to translate the answers from the Latin language. The first signed literary translations appeared in the epoch of the Roman Empire: thus Livy Andronik, a Greek slave translated "Odyssey" into the Latin language in 240 B.C. Livy Andronik was brought as a slave from a Greek town to Rome. There he translated the Greek tragedies and comedies into the Latin language [1].

The introduction of translations in the field of science and engineering in the Empire was related to the dilemma which Rome faced; either to study philosophical and scientific heritage in the Greek language or to use it having translated it into Latin. Rome chose the second way and numerous Greek scientists of the Empire invaded the capital bringing the whole libraries with them. Latin and Greek sections had the same value in a big library founded by August (August- Cesar August- the Roman emperor from 27 to 14 B.C). Thus, there were prepared the conditions for development of translation activity not only in administrative, political and literary fields but also in the field of science. In that period a lot of scientific works were translated: thus in 146 B.C. the Roman Senate ordered Magon, the citizen of Carthage to translate a book on agriculture; Cicero translated a didactical poem "Celestial phenomena" by Aratos, astronomer; Caelius Aurelianus, a doctor (II century) translated Greek tractates "Acute and chronical diseases" and "Feminine diseases" and others into the Latin language )[5]. 
It is interesting to note that there was only one word in the Greek language to denote "to translate" - "hermeneuein" having also the meaning "to explain", but the Romans had a number of synonyms to it: verto, converto, transverto, imitare, reddere, translatare.

While translating the Bible the translators tended to a literal translation as the slightest inaccuracy could cause a grave punishment, but the translators of scientific texts tried to impart the main meaning giving the preference to a "free" translation, explaining the complicated concepts, adding their commentaries.

\section{The fall of Roman Empire.}

In 395 Theodosius the Great divided the Roman Empire between his two sons. Soon the Roman Empire faced religious conflicts that helped Arabs to have easy victories. The Arabs became the successors of the Antiquity precious heritage.

The process of development in the West and East started to acquire different forms. There was a gradual division of Christianity in two directions: eastern (Orthodox) and western, the symbol of which became Catholicism. With disintegration of the Roman Empire into eastern (Byzantine) and western (Rome) one there starts a new medieval cycle of the European translation tradition compared with the ancient one acting in two directions of the southeastern Europe and in the direction of the western and central Europe. [...]That's why two directions of the European translation tradition - western and eastern-European are still being clearly differentiated in spite of their extremely active interaction" [9: 35].

\section{TRANSLATION SCHOOL IN BAGHDAD}

In the middle of the century antique works in the field of science and engineering came to the Western Europe through Arab translations The historical scientific texts translation center became Baghdad. In the ninth century Islamic world reached its highest development in the field of science and culture, the important component of which was development of translation activity. With the arrival of the Abbasid epoch it became possible to speak of scientific texts translation school (the texts translation was so widespread within the IX century that one can speak about Baghdad school, though Arab historians prefer to speak about a "team" or a "group" of translators). In the Abbasid epoch the researchers usually highlight three consecutive periods: from 753 to 813 ; from 813 to 833 and from 919 to the end of the tenth century. The most significant for scientific and technical texts translation was the second period. At that period in 830 caliph Al-Mammon created Greek philosophical and scientific works translation school in Baghdad on the basis of Bayt al-Hikma library ("The house of wisdom/knowledge"). The specific feature of that school was a focused specialization : a translator translated in the field in which he was a specialist (medicine, astronomy, mathematics etc.). The translators strived to form a caste, the representatives of which knew the Syrian and Greek languages besides the Arabic one. The profession of a translator often was transferred from the father to the son. The most prominent man among them was a doctor, philosopher, linguist and translator Hunayan ibn Ishaq (809-875) known in the middle ages under the Latin name of Johannitius. The historiographers often explain the splendid quality of Hunayan ibn Ishaq's translation by his high competence in the field of medicine. The texts translated by Hunayan ibn Ishaq's school were mainly related to the following fields of knowledge: philosophy, science and medicine. Miriam Salama-Carr, the French researcher gives an impressive list of these works: Aristotle, Plato, Porphyry, Euclid, Ptolemy, Hippocrates and others. [13: dissertation of the third cycle of education in the Higher School for written and oral translation in Paris (ESIT) was defended in 1982 within the framework "Science of oral and written translation" and had the name "Hunayan ibn Ishaq's school and its importance in transferring Greek knowledge to the West"]. The works in medicine and 
philosophy as well as in astronomy were of great interest for Arabs and it is proved by the contacts which Muslims kept with India, the country with which they had long trade relations. The selection of texts for translation mainly depended on the state's interests as well as on caliphs' and influential courtiers' personal interests. It is in such a way that Caliph Mansur who was interested in astronomy is likely to have received Indian manuscripts in his favorite subject and made them be translated when he came to power in 753 .

Arabic historians describe that translators received support from patrons and caliphs in the type of generous remunerations and "salaries". Acknowledged translators of that time received about 500 dinars a month. For example, caliph Al Mammon paid gold to Hunayan. The history tells that when Hunayan translated medical texts the caliph paid him in gold equivalent equal to the weight of translated manuscripts. The translator became very rich rewriting his translation on a very heavy paper. Being the distributor of knowledge the translators also searched for manuscripts. The history has a lot of examples when customers and translators applied great efforts to get Greek scientific manuscripts and to prove their authenticity. The number of scientific text translations in the "House of Wisdom" permits to draw a parallel between scientific-technical and fiction texts. So-called fiction translations were more widely spread than scientific ones because they were addressed to a wider range of readers, but the scientific texts translations were not less numerous though they were distributed in less quantity and in a narrower circle of specialists. It should be noted that Arab translations were not aimed at only highly educated part of the population. Of course, the translations were more often aimed at the customer (patron, scientist or caliph) but they also had a didactical trend. For example, Hunayan, a doctor-translator often translated in the field of medicine for his students, calling them for paying a particular attention to clarity and under stability of their translations. The translation was fulfilled as follows: the publisher ordered the text to an acknowledged translator. The latter if had a lot of work transferred the text to a less competent translator. In view of this the first version made by an editor or "negro" was properly corrected several times by an "official" translator. Then the publisher handed over the second version to a writer to work with the style. The same was also done with works of translatorsspecialists. Their work was looked through by an "official" translator and/or a writer. Some translators of the IX century used a literal translation when a word was a unit of translation. In this case a meaning of each Greek word was analyzed, its equivalent was found and written , then the next word was taken.

Hunayan ibn Ishaq was at the origin of the second type of translation: the phrase was read as a whole to understand the meaning and then a translator represented the understood meaning without taking care of the separate words meaning. That's why Hunayan's translations, as a rule, did not need corrections with the exception of the cases when the fields were not his specialization as ,for example, mathematics. The translators loyal to a medieval tradition accompanied their translations by commentaries, resumes and explanatory texts which bore a new knowledge, urged to discussions. This personal contribution testified not only the wish to make a translated text more understandable, but also the desire to supplement it giving the answers to the put questions. The creativity while translating scientific texts was also manifested in a terminological aspect. On the one hand, the first Arab translators often used transliteration, because they insufficiently knew the Arabic language, on the other hand, there was not still formed philosophical and scientific vocabulary in that language. During reconsideration of these translations in the next century the terms-transliterations were replaced by neologisms which more corresponded to morphological structures of the Arabic language. It is possible to say that Hunayan ibn Ishaq and his school laid the foundation for a scientific-technical dictionary creating new terms or imparting a specific meaning to already existing ones but not used in the science language. Thus, we see that the translation in the 
Middle Ages was a creative work as it assisted to formation of the fundamentals for the whole system of Arab-Muslim science, both in conceptual tools aspect and in enriching the Arabic language. To finish this section let's add that the "House of Wisdom" gave an impulse for Arabs to master Chinese, Indian, Persian and especially Greek heritage. This intensive translation activity was continued in all Arab Empire up to its fall in the XIII century. Only due to it " impressive number of Greek scientific and philosophical works was translated into Arab and [...] this heritage of Antique Greece was assimilated and introduced into Arab-Muslim civilization to become an integral part of its foundation" [13: 31].

The translated works served as a raw material for translators and scientists on the basis of which they developed their own researches to transfer them later in their turn to the western world. This new stage of mankind knowledge transfer from one culture to another took place in Spain in the XII and XIII centuries. The translation capital moved from Baghdad to Toledo.

\section{SCHOOL OF TRANSLATION IN TOLEDO}

Toledo replaced town Cordu (caliphate Cordu fell in 1031), which was the main cultural center of Islam. Not only original works of Arab scientists but also numerous translations from the Greek language into the Arabic one were collected in its libraries. The fall of Moors' reign in Spain made these libraries accessible for the Christian world and gave an impulse to the unique phenomenon in the history of mankind and the most important history of translation: Toledo like a magnet began to attract the scientists from all the corners of Europe. The works of the school in Toledo, in such a way the translations made in Spain in regions of the towns Toledo, Barcelona and Tarragona in XII and XIII centuries usually being called, are the main landmarks in transferring philosophical and scientific knowledge in the Middle Ages. Relying on philosophical and scientific works of the Greek-Arab heritage (works in the field of medicine, astronomy take a privileged place), these translations were mainly fulfilled from the Arabic language into Latin in XII century and from the Arabic language into a vulgar Spanish in the XIII century. They made a great influence on the development of a scientific thought in the Western Europe having considerably broadened the understanding of the World and gave a possibility to become familiar with the Arab calculation and algebra, to open the system of Ptolemy's world and to know the medical idea of the Greek-Arab world.

The translation of scientific works from the Arabic language into Latin started in the middle of the $\mathrm{X}$ century. At that time long abstracts of eastern scientific works were being created in the north of Spain but without indication of the author and the translator's names. Only from the beginning of the XII century a serious, systemized and author's translation activity started. In 1135 the bishop Raymond being the head of the church from 1125 to 1152 founded a college of translators, a real school with lessons being conducted and where Italians, the French, the English, the Flemish, the Jews together with the Spanish fulfilled translations under the protection of the church. The translators faced a difficult task : to present a large material in the Latin language so that to use these scientific achievements and to transfer them to new generations. A translator very often set forth to find these manuscripts. Some translators left native countries and set out for searching "Almagest" by Ptolemy as, for example, Gerardo, an Italian from Cremona (1114-1187), Scot from Scotland (1175-1234), Abelard, an Englishman from Bata (1130). Coming back to their country they taught their students to what they came to know during their trips. The translations made definitely assisted to distribution and exchange of knowledge but was exchange of knowledge mainly among specialists as in the society-recipient only a limited number of educated people had an access to scientific works. The translators of the XII century were not a homogenous group inspired by a sovereign as it was in the XII century under the rule of Alphonso X (1221-1284) but they were a kind of educated Latin's representatives for the most part the members of the Catholic church. The 
type of knowledge transfer in that epoch was based on citing and commentaries. While translating scientific texts formal transformations were used that were aimed at creating texts corresponding to the norms of the Latin language, the paragraphs related to historical and geographical realia of the Arab world, were omitted. Mass use of transliterations (the technique that assisted to appearance of a big number of unknown and unclear words in the Latin language), often application of semantic borrowings (the device with the help of which a certain scientific meaning was imparted to the word existing in the language of translation) and the presence of acronyms (which not a single book helped to decipher) points to the fact that a translator did not take care of the presentation clarity but rather found his activity as the means to broaden his own knowledge than to share it with others. The most important men in the field of translation of scientific and technical texts are Juan from Seville, Dominikus Gundisalve and Gerardo from Cremona. Juan from Seville translated Persian books on mathematics and astronomy due to which the Arab numerals were finally introduced on the Iberian peninsula. Dominikus Gundisalve translated "Metaphysics" by Avicenna and "The source of life" (Fons Vitae) by Avicebrona, the Spanish philosopher (Garcia Yebra, 1983, p.311). Gerardo from Cremona came to Toledo in 1167 dreaming to familiarize with Ptolemy work "Almagest". Finished by him in 1175 the translation is a kind of tractate on astronomy and a compilation of the Classical Antiquity mathematical knowledge. Gerardo's from Cremona translations which are 74 in number, are mainly related to the fields of mathematics, physics, astronomy, alchemy, medicine. In XIII century adoption of the Spanish language as the language of translation and demand for clarity of translated texts of such a patron as Alfonse X for whom the texts, according to his own words, had to be llanos de entender (easily understood) is a proof of a tendency not to limit the translated knowledge by a narrow circle of specialists. With improving the conditions for translators' activity (appearance of assistants for the main translator) the concern about the distribution of knowledge grows, the importance of the text in a vulgar language for omnes entendudos, i.e. for educated people was often pointed to in introductions to translated scientific works. At that time a considerable work to define and create lexicography was performed.

The School in Toledo combined the culture of two different communities (Christian and Muslim worlds). Retardation in the field of culture and science of the Western Europe from the Arab world could not help leading to the thirst for knowledge which explains why so many brilliant minds preferred to dedicate themselves to translation but not to scientific researches. Thus, they became the guarantor of the Classical Antiquity knowledge transfer and were aware of the importance of their mission.

\section{PROFESSIONALLY-ORIENTED TRANSLATION IN THE MIDDLE AGES. Professionally-oriented translation in France.}

Till XV century the translation activity was rather weakly developed. The first French universities emerged (in Montpellier in Paris) were not able to collect big libraries as the scientific manuscripts were expensive and few in numbers. It was an obstruction for a scientific progress and consequently for development of a translation activity. Only in the period of the king Karl V reign (1338-1380) who collected about a thousand of manuscripts in the Louvre tower and formed a royal library the scientists were invited to translate most prominent scientific and philosophical works of the Classical Antiquity. Translation into the French language was made from the Latin versions. Karl V insisted on the precision, legibility and facility of translation texts understanding (Kalinin, 1999, p.154). The lack of many terms in the French language caused a necessity to create new words. Nickola Orem (Nicolas Oresme 1330-1380) declared the right for translators to create scientific and technical terms in the introduction to his translation of one of Aristotle's works [5: 26]. Unfortunately Karl's V undertaking was left without development and till the end of Louis XII reign the role of 
translations in the field of science in the French language remained very humble. Development of book printing resulted in increase of translations number. The starting point of book printing in Europe was the creation of the hand printing press by Johann Gutenberg, a German inventor in the XV century. The first printing office in France located in Sorbonne buildings was organized by the humanist Jean de Pierre (-496). There appeared the class of readers who though did not know the Greek language or Latin but they wanted to be familiarized with scientific and philosophical works of the Classical Antiquity. It was at that time when a new concept of translation was formed. Introduction of the verb traducere by Italian humanists terminated a numerous synonymy, which prevailed before. The verb traduire created by the lexicographer and translator Robert Etienne in 1539 (1503-1559) from the base of which Etienne Dole (1509-1546) formed the words traducteur and traduction next year (Hoof van, 1991, p.30). The contacts of Karl VIII contemporaries with the representatives of the Italian Renaissance had a great influence on the development of the French language and the fate of translation in the West. At that time very few translators knew the Greek language. The Latin language mainly dominated in science. The Pleiad returned the Greek to life calling for addressing again the antique originals imitating them while translating, thus introducing the beauty into the French language. I.V.Kalinin notes that "the leading method of translation that rejects a literal translation for the sake of under stability and elegancy of the expression appears at the end of the Middle Ages , which was popular till the beginning of the XIX century" [6: 154].

However, at that time two other directions began to take shape: on the one hand, there appeared the interest in the translation of the modern foreign fiction, on the other hand- in the translation of special scientific and technical literature almost forgotten since the time of "The House of Wisdom" and School in Toledo. Together with translation of Greek and Roman heritage there appeared a big number of translations from the Italian, German languages of modern scientists' works in the field of astrology, mathematics, medicine, agriculture and geography( the impressive lists of these translation is given by Van Hoof, the translation researcher) [5: 42-4]. Achievements of Greece and Rome in the field of mathematics, geometry, mechanics and some other fields were of great importance. Nevertheless, it's generally accepted that the basics of a modern science were laid only in XV-XVII centuries and it is first of all related to the names of G. Galileo and I. Newton [7: 16]. The science ran out of the church control in the epoch of Renaissance, the French language began to gradually force out the Latin language from the science. Scientists -humanists Pare, Palissi, Ramus, Belon, Bowel and many other representatives of the French Renaissance wrote their scientific works in French. The known mathematician Forkadel who also wrote his works in French translated the works of Archimedes, Euclid, Proclus into French [11: 116]. The application of the French language in the science lead to the creation of the French science language terminological dictionary - Le Dictionnaire de medicine by Henri Etienne (1564).

\section{Professionally-oriented translation in Russia.}

Byzantine had a great influence on the medieval Russia. After the fall of the Roman Empire Byzantine continued to support the traditions of education, literacy, developed such sciences as astronomy, medicine, natural sciences. However the spiritual life in Byzantine was under the control of church and the state. There happened the transformation of the Antique ideas, the views formed on the basis of the orthodox tradition were established in mentality [15: 82]. Byzantine managed to spread an orthodox doctrine, to bring an evangelistic preaching to other peoples, especially to the Slavs. In 864 a Greek monk Kirill and his brother Methodius (825-85) were sent by Byzantine emperor to spread Christianity among Slavonic peoples. Both monks knew the ancient Slavonic language which did not have writing yet. The brothers created the alphabet (kirillitsa) and translated the New Testament, Psalter and Book of Common Prayers 
from the Greek into the Ancient Slavonic. Adoption of Christianity in Rus took place in 988. After adoption of Christianity a great world of new Byzantine images and ideas was opened for Russian bibliophiles. Rus was familiarized with philosophical and scientific heritage of the Greek Classical Antiquity through this literature. However, the orientation in the spiritual field to Byzantine cut off the Ancient Rus (and then Russia) from the Antique heritage in its original state. In Russia the Antique heritage was assimilated either in "the kind of western", Byzantine variant, or later in "renaissance, European type' [15: 178].

Mongol-Tatar invasion in XIII century considerably hindered economic-political and cultural development of eastern Slavonic states. Nevertheless, Rus did not interrupt trade relations with Europe, had contacts through pilgrims, travelers, diplomats and merchants with many countries of the world.

In the period of Ivan III (1462-1505) reign the Mongol-Tatar yoke was finally overthrown. Unification of Russian territories into Moscow state created prerequisites for development of the national culture and thereby for the development of science and engineering. Administrative and military reforms conducted by Ivan IV (the Terrible, 1530-1584) assisted to the further dissemination of scientific knowledge. The famous scientist N.M. Karamzin wrote that Ivan the Terrible" loyal to his intuition "showed "respect to the arts and sciences, cherishing foreigners". In 1564 there appeared the first book printed in Russian. The translations became an important part of Ancient Slavonic bookishness. These translations , as a rule, were fulfilled by Greeks and the translation language was "artificial written general Slavonic". The main intermediate and conveyer of translated literature was Bulgaria [14: 214]. However, all the literature being translated was strictly controlled by the Russian church not permitting any deviations from the Christian Orthodoxy, any novelties, especially of the Western sense. Nevertheless, it should be noted that all theological literature was based on Aristotle's cosmology. Naturally, scientific ideas though in Christian-symbolic interpretation got into Rus through such translations as "Physiologist", "Hexaemeron" in which the data on astronomy besides other ones was based on the achievements of the Antique science: planets, zodiac constellations, sizes of celestial bodies, equilibrium, obliquity of ecliptic etc. All this was presented "from the point of view close to a natural-scientific one, almost not resorting to interaction of divine power [2: 59].

"Hexaemeron" - the work of philosophical-theological character consisting of six treatises and explaining the questions of the universe was widely spread in Rus up to XVIII century and is definitely important for the history of scientific and technical texts translation. The most known are "Hexaemeron" by Basil the Great and "Hexaemeron" by John , Bulgarian exarch (lived in the capital of Bulgaria in IX century) which presents itself a translation of "Hexaemeron" by Basil the Great, as well as a compilation from works of George Nissky, John Damaskin, Aristotle, Democritus and others. The following works in ancient Russian translation as "Metaphysics " by Aristotle, "Cosmography" with Euclid' s geometrical fragments, "Hexaemeron", "Lucidarius" rightly belong to XV century. Some texts were already translated not only from the Greek but also from the Latin and the ancient Jewish. "Logics" by Avfisafus, "Privy of secrets" are related to them. [2; 10; 12]. The Ancient Slavonic translations in general and Russian ones, in particular, were mostly anonymous. The first famous Russian translators were Dmitry Gerasimov (died about 1530) and Blaise who worked under protection of Gennadius, archbishop of Novgorod to make up a complete Biblical code. For this purpose it was required to translate a number of books that lacked in Slavonic translations . In the first part of XVI century Maximilian Transylvan's work about Moluccas islands, Magellan's sailing got into Rus and was translated. Dmitry Gerasimov is supposed to have been a translator. The translation was almost literal, even the Latin syntax was reproduced and the 
facts, which according to the translator's opinion led the story astray or were extra, were omitted [14: 233].

Later on the center of translation activity was moved from Novgorod to Moscow. In the beginning of XVI century Athos scientist, the monk Maximus the Greek came to Moscow at the invitation of Grand duke Basil III. He did not know the Church Slavonic language, that's why initially his translations were made in two stages (he translated from the Greek into the Latin language and then his assistants translated from the Latin into the Old Slavonic language. Maximus the Greek was a very educated person, he knew the Latin language besides his native Greek and, probably, the Italian, he had a deep knowledge and thought that a translator had to be a highly educated person to know not only the language but also all the grammatical and language nuances, spoke about the necessity of a proper analysis of the text [4].

At that period there existed two styles in Rus: literary (in which bookish and common means of the language were intersected, the Old Slavonic vocabulary and morphological archaisms were present) and a business one (which accepted to be called a mandatory language and which was used to make up business documents, legal acts of the official and private correspondence.)

The written language remained the Old Slavonic one (the Old Church) [16: 63-66]. In most cases the earlier translations of scientific works were literal that's why often unclear. The translators' desire to interpret numerous lexical and syntactical specific features of the Greek language led to a lot of mistakes and inaccuracy. Translators had to invent terminology [14: 215-222].

Thus, by the end of the XV century the Antique scientific works had been translated from the Latin language. The French language gradually superseded the Latin one. The science comes out of the church influence. Modern scientific works were translated from the Italian and German languages together with the translations from the Latin language. There appeared the first author's translations of scientific and technical texts. The translators reject a literal translation, new words are created due to the absence of corresponding terms in the French language. In XVI century, in the epoch of knowledge popularization the fundamentals of the French science language terminology were laid.

In XVI century in Russia mainly religious texts were translated in spite of a considerable number of translations of the western European and Greek literature in the field of science and engineering. The scientific ideas came only through a theological literature. The works in the field of science and engineering were translated from the Greek into the Old Slavonic language, which was an artificial language because it was written but not spoken one. The translations often were anonymous. A literal translation was mainly used till the XVII century. Though, a translation-retelling is also known, however, it was rarely used compared with European states. Nevertheless, it was already noted the importance of background knowledge for a translator, the need to know both languages: original and translation ones. But there were not big translation schools yet.

\section{CONCLUSION}

The knowledge of professionally-oriented translation stages of formation for translators will help to deeper understanding of translation process, its role in the development of a scientific thought and a conscience choice of the translation strategy. Training a special course "History of scientific and technical texts development ", besides knowledge in the field of professionallyoriented texts translation, gives a possibility for students to increase knowledge in such fields 
as the history of the studied language country, the history of science and engineering development, formation of the science language in the given country and will assist to formation of professional translator's intercultural competency. On the basis of the given special course it is advisable to design manuals aimed at familiarization of the most known scientists and their main discoveries and achievements in the country of the language being studied and in Russia.

\section{REFERENCIES}

Barankova G.S. "On astronomical and geographical knowledge// Natural sciences ideas of Ancient Rus', M., Nauka, 1978: p.48-62

Vinokur G.O. "Selected works in Russian language”, M., AS USSR, 1959, p.492

Gromov M.N. "Maximus the Greek", M., Publishing House "Mysl”, 1983, p.198

Kirillin V.A. "Pages of science and engineering history”, m., Nauka, 1989, p.494

Komissarov V.N. "Modern translation science” Course of lectures, M., ETS, 1999, p.192

Kopanev P.I., Beer F. "Theory and practice of written translation”, Part I. Translation from German into Russian. , Minsk, Higher school, 1986, p.270

Kalinin K.A. "History of translation in France and Francophone Canada// Notebooks of translator, M. MGLU publishing house, 1999, issue 24, p.153-164

Kuzakov V.K. “ National historiography of science history in Russia X-XVII centuries”, M., Nauka, 1991, p.359

Kuznetsov V.G. Functional styles of modern French language (publicistic and scientific). M., Vyshaya shkola, 1991, p.160

Raikov B.E. "Essays on history of heliocentric outlook in Russia. The 2nd edition, M., L, AS USSR publishing house, 1947, p.391

Semennikova L.I. "Civilization in history of mankind” , Bryansk, Kursiv, 1998, p.340

Semenets O.E., Panasyev A.N. “History of translation “ , K. , Kiev university publishing house, 1989, p.296

Ballard M. “De Ciceron aBenjamin" Presses Universitaire de Lille, 1992, p.301

Garsci YerbaV "Teori y pratica de la traduccio”, Madrid, Ed. Gredes, 1984, p.874

Hoof van, H “Histoire de la traduction en Occident", Paris, Duculot, 1991, p.368

Salama-Carr M “Traduction al'eoque abasside”, Paris, Didier, 1990, p.122 